\title{
MOLECULAR AND CELLULAR FEATURES OF MANDIBULAR AUTOGRAFTS STUDIED USING RAMAN SPECTROSCOPY
}

Maksimov GV ${ }^{1,4} \bowtie$, Sashkina TI², Fashutdinov DK ${ }^{3}$, Slatinskaya OV' ${ }^{1}$, Saldusova IV ${ }^{5}$, Zaychenko OV ${ }^{5}$

${ }^{1}$ Lomonosov Moscow State University, Moscow, Russia

${ }^{2}$ Pirogov Russian National Research Medical University, Moscow, Russia

${ }^{3}$ A. I. Yevdokimov Moscow State University of Medicine and Dentistry, Moscow, Russia

${ }^{4}$ National University of Science and Technology MISIS, Moscow, Russia

${ }^{5}$ Central State Medical Academy of Department for Presidential Affairs of the Russian Federation, Moscow, Russia

Currently, biophysical studies are of great interest, the results of which are important for development of a method for diagnosis of the cells and tissue condition to be used in clinical practice. The study was aimed to use a non-invasive optical method (Raman spectroscopy) for assessment of changes in the composition and conformation of the molecules of the patient's mandibular cells and tissues. This approach was proposed to increase the informativeness and effectiveness of studying the composition of autografts harvested for augmentation of alveolar processes with bone tissue deficiency (elective bone grafting). In the course of the study the bone tissue samples obtained from three patients aged 51-73 (two men and one woman) were assessed. Raman signals were detected, indicating the presence of phosphate groups and carbonate ions (such as $\mathrm{CO}_{3}^{-2}$ ) of the inorganic bone components. Raman bands indicating the presence of collagen, red blood cell hemoglobin, proteins ( $\mathrm{C}-\mathrm{N}$ bonds), lipids ( $\mathrm{C}-\mathrm{H}$ groups of fatty acids and phosphate groups of phospholipids), as well as their $\mathrm{OH}$ groups may be considered the markers of periosteum tissue. The general possibility was suggested of studying single cells of autografts using the markers, indicating the presence of collagen, hemoglobin, proteins, lipids (C-H groups of fatty acids of lipids; phosphate groups of phospholipids), and their OH groups. According to the authors, the results obtained can provide a basis for development of the new method for diagnosis of autograft bone using the combination of Raman spectroscopy and light guides. Keywords: autograft, implant, bone tissue, Raman spectroscopy

Author contribution: Maksimov GV — study planning, analysis of the results; Sashkina TI — study planning, literature analysis; Fashutdinov DK — data acquisition and analysis, performing bone grafting; Slatinskaya OV — data processing; Saldusova IV — data analysis; Zaychenko OV — technical support.

Compliance with ethical standards: the study was approved by the Ethics Committee of the Central State Medical Academy of Department for Presidential Affairs of the Russian Federation (protocol № 3 dated September 23, 2021); the informed consent was submitted by all participants; biomaterials were treated in accordance with the World Medical Association Declaration of Helsinki.

$\triangle$ Correspondence should be addressed: Georgy V. Maksimov

Leninskie Gory, 1, str. 24, Moscow, 117042; gmaksimov@mail.ru

Received: 13.05.2021 Accepted: 31.05.2021 Published online: 17.06.2021

DOI: $10.24075 /$ brsmu.2021.028

\section{ИССЛЕДОВАНИЕ МОЛЕКУЛЯРНО-КЛЕТОЧНЫХ ХАРАКТЕРИСТИК АУТОТРАНСПЛАНТАТОВ НИЖНЕЙ ЧЕЛЮСТИ С ПОМОЩЬЮ МЕТОДА СПЕКТРОСКОПИИ КОМБИНАЦИОННОГО РАССЕЯНИЯ}

Г. В. Максимов ${ }^{1,4}$, Т. И. Сашкина², Д. К. Фасхутдинов ${ }^{3}$, О. В. Слатинская', И. В. Салдусова ${ }^{5}$, О. В. Зайченко

${ }^{1}$ Московский государственный университет имени М. В. Ломоносова, Москва, Россия

${ }^{2}$ Российский научно-исследовательский медицинский университет имени Н. И. Пирогова, Москва, Россия

${ }^{3}$ Московский государственный медико-стоматологический универститет имени А. И. Евдокимова, Москва, Россия

${ }^{4}$ Национальный исследовательский технологический университет «МИСиС», Москва, Россия

${ }^{5}$ Центральная государственная медицинская академия Управления делами Президента Российской Федерации, Москва, Россия

В настоящее время большой интерес представляют биофизические иссследования, результаты которых важны для формирования методологии диагностики состояния ткани и клеток в клинической практике. Целью данной работы было продиагностировать изменения состава и конформации молекул клеток и ткани нижней челюсти пациента с помощью оптического неинвазивного метода (спектроскопия комбинационного рассеяния (КР). Данный методический подход предложен для повывшения информативности и эффективности исследования состава аутотрансплантатов, полученных для аугментации альвеолярных отростков при десиците костной ткани (планируемая костная пластика). В исследовании использовали образцы костной ткани троих пациентов в возрасте 51-73 лет, двоих мужчин и одной женщины. В костной ткани обнаружены КР-сигналы, свидетельствующие о наличии фосфатных групп и карбонат-ионов (типа $\mathrm{CO}_{3}^{-2}$ ) минеральных компонентов кости. Маркерами молекул околокостной ткани могут быть полосы, которые свидетельствуют о наличии коллагена, гемоглобина эритроцитов, белков (C-N-связи), липидов (C-H-групп жирных кислот и фоссатных групп фосфолипидов), а также их ОН-групп. Показана принципиальная возможность исследования отдельных клеток аутотрансплантатов с помощью маркеров, свидетельствующих о наличии коллагена, гемоглобина, белков и липидов (С-H-групп жирных кислот липидов; фосфатных групп фосфолипидов), и их ОН-групп. По мнению авторов, результаты могут служить основой для формирования новой методологии диагностики костных аутотрансплантатов с помощью совмещения КР-спектроскопии и световодов.

Ключевые слова: аутотрансплантат, имплантат, костная ткань, спектроскопия комбинационного рассеяния.

Вклад авторов: Г. В. Максимов - планирование работы, анализ результатов; Т. И. Сашкина - планирование работы, анализ научной литературы; Д. К. Фасхутдинов - сбор и анализ исследуемого материала, проведение операций аугментации костной ткани; О. В. Слатинская - обработка полученного материала; И. В. Салдусова - анализ полученных результатов; О. В. Зайченко - техническая поддержка.

Соблюдение этических стандартов: исследование одобрено этическим комитетом Центральной государственной медицинской академии Управления делами Президента Российской Федерации (протокол № 3 от 23 сентября 2020 г.); все участники подписали добровольное информированное согласие на участие в исследовании; работы с биоматериалами проведены с соблюдением требований Хельсинкской декларации Всемирной медицинской ассоциации.

$\triangle$ Для корреспонденции: Геогрий Владимирович Максимов

Воробьевы горы, д. 1, корп. 24, г. Москва, 117042; gmaksimov@mail.ru

Статья получена: 13.05.2021 Статья принята к печати: 31.05.2021 Опубликована онлайн: 17.06.2021

DOI: $10.24075 /$ vrgmu.2021.028 
It is known that dental implants are being successfully used to restore the dental arch continuity in partially and completely edentulous patients [1, 2]. The patients of the dentists often present with significant bone loss in the alveolar process and a part of the jaw, which suggests the procedure to increase the amount of bone tissue prior to implant installation. Bone augmentation is performed using both allo- and autografts, however, it is better to use autografts $[3,4]$. Autogenous cortical bone grafts are good for that, harvested from various extraoral body areas: iliac crest, skull cap, tibia, zygomatic bone, as well as the intraoral sites (rami of the mandible, sites within the retromolar region, chin area). Intraoral autogenous bone grafts are used more frequently, since the harvesting procedure is less invasive, surgical approach is more convenient, and the installation procedure is less time-consuming. It is also essential that the distance between donor and recipient sites becomes closer $[5,6]$.

Osteoregeneration process depends on a number of factors: microarchitectonics, bone density, percentage of cortical and cancellous bone, as well as the levels of pro- and antiinflammatory cytokines, the markers of bone destruction and regeneration [7-10]. It is well-known that jaws are flat cancellous bones organized into trabeculae. Trabeculae form the shell for red bone marrow, which is responsible for hematopoiesis and blood cell production [11]. Type 1 collagen accounts for 95\% of trabecular plate; trabecular plates also contain collagen types 3, 4, 5, 11, and 12 (the other 5\%). There are noncollagenous proteins, osteocalcin, osteonectin, osteopontin, bone sialoproteins, phosphoproteins, morphogenetic proteins, and proteoglycans in the intercellular space. Moreover, there are glycoproteins: alkaline phosphatase, osteonectin, thrombospondin, fibronectin, vitronectin, osteopontin, sialoprotein, Wht-glycoproteins. Inorganic components, represented by the hydroxyapatite crystals, account for 30\% of bone tissue structure. Bone also contains hydroxyapatite stability regulators: magnesium, strontium and manganese.

Cellular composition of bone tissue consists of osteoprogenitor cells (early progenitors of osteoblasts), osteoblasts, osteocytes, bone lining cells, and osteoclasts. Mature osteoblasts produce type 1 collagen, proteoglycans, and osteocalcin. Immature osteoblasts lay directly adjacent to periosteum. The cytoplasm of those contains small quantities of glycogen granules. Osteoblasts are cells that synthesize bone matrix, cytokines, and growth factors. Alkaline phosphatase and osteocalcin are the osteoblast markers (osteocalcin is the main marker of bone tissue regeneration). Osteocyte formation is the final stage of osteoblast differentiation. Osteocytes do not synthesize bone matrix; osteocytes are involved in osteolysis and metabolic transport. Osteoclasts, being the large multinucleated cells, are responsible for bone resorption. Osteoclasts priduce hydrogen ions together with enzymes (cathepsin and collagenase) involved in the lysis of organic matrix. Alkaline phosphatase is the marker of osteoclasts. The outer surface of spongy osseous tissue is covered by cortical bone, which in turn is covered by periosteum, invaded by blood vessels feeding the bone. The internal layer of periosteum contains osteoblast progenitor cells responsible for bone growth and remodeling [11]. Studying the structure and components of bone tissue is essential for evaluation and forecasting of regeneration, osteogenesis and osseointegration when performing dental implantation [12].

Clearly, it is important to put advanced effective, reliable and non-invasive optical methods, allowing one to allocate the components of bone tissue, oral fluid, and peripheral blood, into dental practice in order to monitor bone tissue structure, resorption and remodeling. Assessment of bone-to-implant integration and augmentation of the alveolar processes is relevant to surgical dentistry, and is of crucial importance, since it determines the success of treatment.

Prompt diagnosis of osseointegration and bone tissue regeneration impairments is essential. Markers of resorption and regeneration, as well as bone tissue protectors, are wellknown. There is a number of methods for detection of those. Biochemical analysis makes it possible to evaluate the treatment and complication prevention results, however, the analysis requires a fairly large amount of the material being sampled. Gas chromatography is a more accurate method, which has the advantage of high reliability of the results. The method's disadvantages are as follows: considerable complexity of investigation, high cost, time-consuming interpretation of the results, and the need for expert assessment.

In recent years, many optical methods have been used in biology and medicine. One of the methods is Raman spectroscopy, the highly sensitive optical method providing express and accurate determination of the composition and conformation of molecules, constituting biological objects: cells, cell fragments, bacteria, viruses, proteins, peptides, lipids $[13,14]$. It is worth mentioning that in dentistry there is an emerging body of research using both Raman spectra and giant Raman spectra acquisition [15]. Such approach exhibits high sensitivity; it has been used for identification of the main pathogens of purulent-inflammatory processes in maxillofacial area [16]. What's important is that with the use of giant Raman scattering effect, certain markers of the pathogens have been detected: in Bacillus subtilius there were peaks at 657,726 , $1248,1377,1466,1617 \mathrm{~cm}^{-1}$; in E. coli these were found at $1140,1551 \mathrm{~cm}^{-1}$; in $S$. aureus peaks were found at 959, 1006, $1160,1284,1530 \mathrm{CM}^{-1}$; in S. haemolyticus there were peaks at 1327, 1369; in Ps. aeruginosa these were found at 675, 1353, 1404, 1605, $1630 \mathrm{~cm}^{-1}$. Thus, giant Raman spectra acquired during treatement make it possible to determine the cause of the inflammation. However, this approach needs firther detailed testing in practice, since the giant Raman scattering effect realization requires the use of nanoparticles (colloidal silver and gold nanoparticles), the toxic effect of which on the cells and tissues of the oral cavity is not yet khown.

Taking into account the informative nature and efficiency of Raman spectroscopy, as well as lack of time-consuming sample preparation, it is important to develop the Raman scatteringbased technology for assessment of osseointegration after installation of dental implants in order to define the condition of autograft bone, as well as to search for markers of osteogenesis, resorption and osseointegration involved in the process of reparative regeneration.

The study was aimed to investigate molecular and cellular composition of mandibular autografts using Raman spectroscopy.

\section{METHODS}

Augmentation of the mandible prior to implant installation was performed during the study. For this purpose the patients underwent surgical restoration of bone tissue amount using autografts, the condition of which was investigated later. Four samples of cortical and cancellous bone tissue obtained from the left and right retromolar regions of the mandible during the surgical procedure were assessed (see Table). Four autografts were investigated, obtained from three patients aged 51-73: two men and one woman. Inclusion criteria: no somatic pathology; medium-sized mandibular bone defect; no 
Table. Studied samples

\begin{tabular}{|c|c|c|c|c|}
\hline 1 B-v R.E. & Retromolar region & 1969 & Dental Clinic 2 of MSUMD & Dental Clinic 2 of MSUMD \\
\hline 2 A-a S.G. & Retromolar region & 1947 & Dental Clinic 2 of MSUMD & Dental Clinic 2 of MSUMD \\
\hline 3 P-a M.L. & Retromolar region & 1961 & Dental Clinic 2 of MSUMD & Dental Clinic 2 of MSUMD \\
\hline 3 P-a M.L. & Edentulous area (mandibular tooth 6) & 1961 & Dental Clinic 2 of MSUMD & Dental Clinic 2 of MSUMD \\
\hline
\end{tabular}

drug intolerance; age 40-60 years. Exclusion criteria: severe somatic illness; drug intolerance; large-sized mandibular bone defect; age under 40 and over 60.

\section{Bone block harvesting from the donor site}

After giving the conduction and infiltration anesthesia (sol. Articaini $3.4 \mathrm{~mL}$ ), the incision was made across the mandibular alveolar process apex in the area of missing teeth, mucoperiosteal flap was peeled off, mandibular alveolar bone was exposed, and the length and width of the bone defect were defined. After giving the conduction and infiltration anesthesia (sol. Articaini $3.4 \mathrm{~mL}$ ), the $3 \mathrm{~cm}$ incisions were made in the left and right retromolar regions, mucoperiosteal flap was peeled off. Using the disc with a protector and the fissure burr, autograft sized $2 \times 1 \times 0.3 \mathrm{~cm}$ or $1.5 \times 1 \times 0.3 \mathrm{~cm}$ was harvested. The autograft bone was split into two thin bone plates using the disc. The wound was closed by the 4-0 Vicryl suture.

The autograft bone samples (size 0,1 mm) were placed into glass capillaries with cross sectional diameter of $1 \mathrm{~mm}$ (Agat-Med; Russia) filled with buffer (145 MM NaCl, $5 \mathrm{MM} \mathrm{KCl}$, $4 \mathrm{MM} \mathrm{Na}_{2} \mathrm{HPO}_{4}, 1 \mathrm{MM} \mathrm{NaH}_{2} \mathrm{PO}_{4}, 1 \mathrm{MM} \mathrm{MgSO}_{4}, 5 \mathrm{MM}$ glucose (Sigma; USA), $\mathrm{pH}$ 7.4). They were stored at a temperature of $4^{\circ} \mathrm{C}$ for the period not exceeding 3 hours.

Sample morphology and molecular composition of bone tissue, soft tissues and cells of the mandible were studied using Raman spectroscopy. The following settings of the confocal Raman/fluorescence microscopy NTEGRA-SPECTRA system (NT-MDT; Russia) were used: spectral range of $1000-3000 \mathrm{~cm}^{-1}$; step size of $0.8 \mathrm{~cm}^{-1}$; detection with CCD detector with Peltiercooling to $-50^{\circ}$ (objective $20 \times$ with an aperture of 0.15 , grating 600 lines $/ \mathrm{mm}$ ); laser power at sample not exceeding $3 \mathrm{~mW}$, laser excitation wavelength $532 \mathrm{~nm}$, exposure time $10 \mathrm{~s}$, 3 sample exposures. Number of repetitions for the experiment (sample): 12. Spectra processing involved background subtraction and

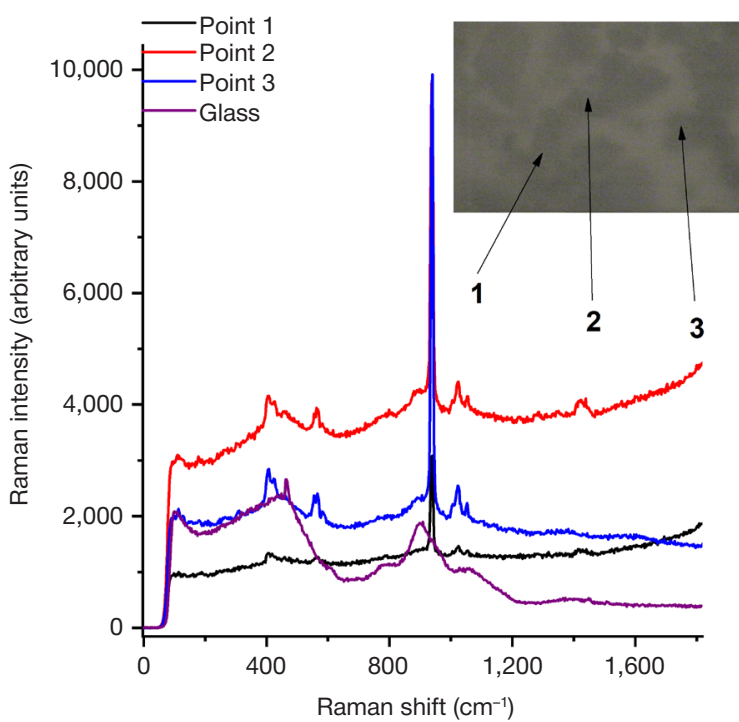

smoothing of spectra using the Origin2017 software (OriginLab Corporation; USA).

The pilot study was carried out in order to define the possibility of using Raman spectroscopy to assess the condition of the tissues in the maxillofacial region; no statistical analysis was performed.

\section{RESULTS}

During the study the sample images and the Raman spectra of the components of autografts (bone tissue, soft tissues and cells), harvested from the retromolar region, were obtained.

\section{Raman spectra of bone tissue of autografts harvested from the retromolar region}

During this series of experiments the analysis of autograft bone tissue markers revealed characteristic Raman bands in the spectra of samples, corresponding to collagen, phosphate groups, apatite $\left(\mathrm{PO}_{4}{ }^{3-}\right)$, type $\mathrm{B}$ carbonate ion (such as $\mathrm{CO}_{3}{ }^{-2}$ ), as well as proteins adsorbed to the cell surface (bending $\mathrm{N}-\mathrm{H}$ vibrations and stretching $\mathrm{C}-\mathrm{N}$ vibrations), lipids ( $\mathrm{C}-\mathrm{H}$ groups of fatty acids of lipids), and their $\mathrm{OH}$ groups.

Thus, in the patient's Raman spectrum of the sample № 2, a number of bands was observed corresponding to phosphate groups $\mathrm{PO}_{4}^{3}\left(563,943,975 \mathrm{~cm}^{-1}\right)$, collagen $\left(1270 \mathrm{~cm}^{-1}\right)$, type $\mathrm{B}$ carbonate ion $\mathrm{CO}_{3}^{-2}\left(1025,1051 \mathrm{~cm}^{-1}\right)$, proteins and lipids (C-H groups of fatty acids of lipids, 2862, 2890, $2946 \mathrm{~cm}^{-1}$ ), and their OH groups (3192, 3420, 3559, $3635 \mathrm{~cm}^{-1}$ ) (Fig. 1). A number of bands were observed corresponding to phosphate groups $\left(426,583,938 \mathrm{~cm}^{-1}\right)$, type $\mathrm{B}$ carbonate ion $\mathrm{CO}_{3}^{-2}$ (1009, 1023, $1056 \mathrm{~cm}^{-1}$ ), proteins (bending $\mathrm{N}-\mathrm{H}$ vibrations and stretching $\mathrm{C}-\mathrm{N}$ vibrations of protein, $1607 \mathrm{~cm}^{-1}$ ), lipids (C-H groups of fatty acids of lipids, 2857, 2889, $2948 \mathrm{~cm}^{-1}$ ), and their $\mathrm{OH}$ groups $\left(3204,3408,3621 \mathrm{~cm}^{-1}\right)$, together with a

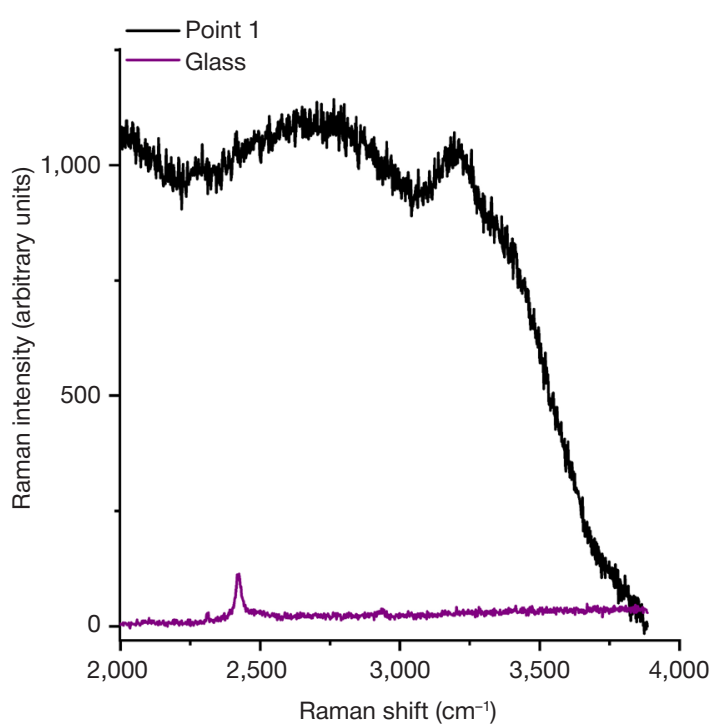

Fig. 1. Raman spectrum of the autograft, sample № 2 (bone tissue and tissue components). The insert in the chart illustrates the image of the sample. The control is the Raman spectrum of the glass, the sample is placed on. X-axis: Raman shift ( $\left.\mathrm{cm}^{-1}\right)$; Y-axis: Raman intensity (in arbitrary units) 

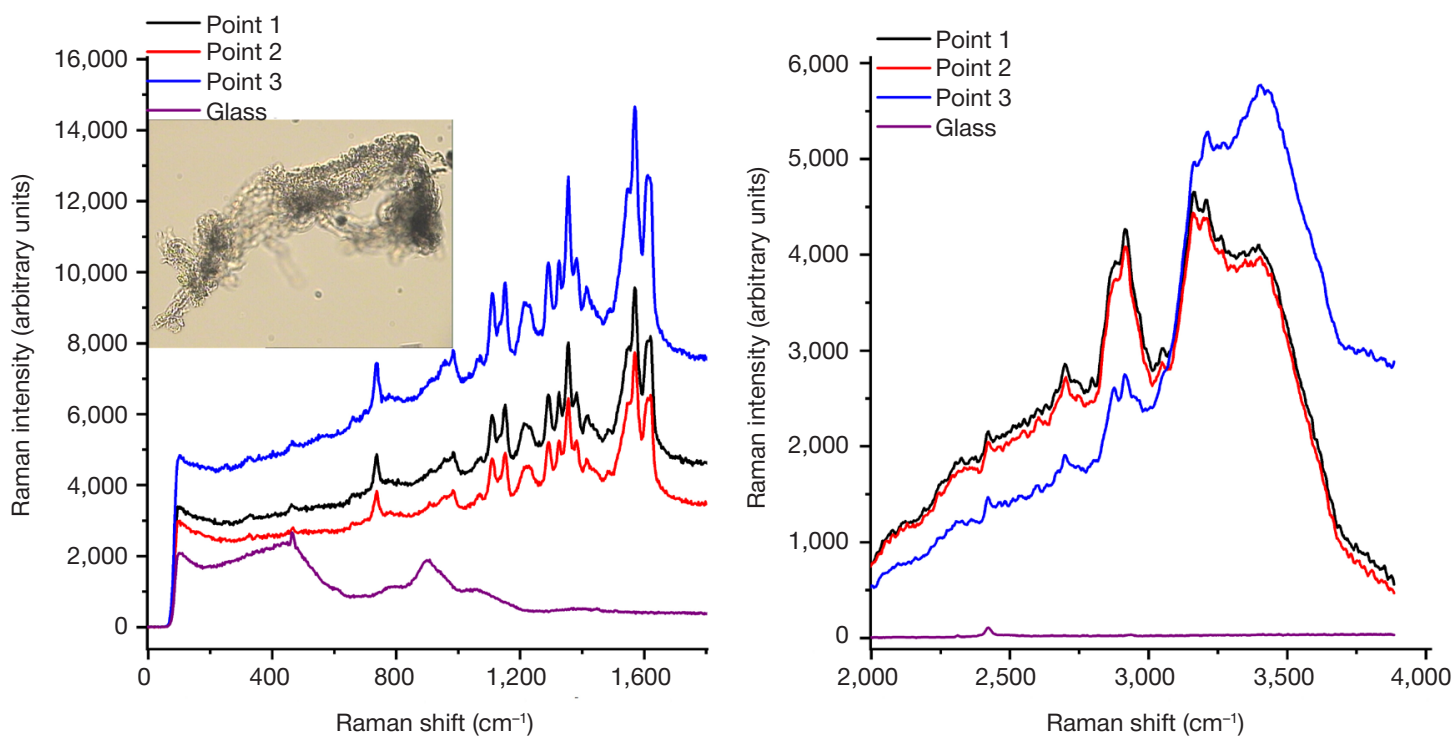

Fig. 2. Raman spectrum of the autograft, sample № 2 (autograft tissues). The insert in the chart illustrates the image of the sample. The control is the Raman spectrum of the glass, the sample is placed on. X-axis: Raman shift $\left(\mathrm{cm}^{-1}\right)$; Y-axis: Raman intensity (in arbitrary units)

number of bands defining the inorganic composition of bone tissue: phosphate groups $\mathrm{PO}_{4}^{-3}\left(415,457,570,580,892,936 \mathrm{~cm}^{-1}\right.$ (phosphate group of apatite)), type $\mathrm{B}$ carbonate ion $\mathrm{CO}_{3}^{-2}$ $\left(1007,1022,1050 \mathrm{~cm}^{-1}\right)$, as well as $\mathrm{OH}$ groups of lipids and proteins, 3209, 3399, $3625 \mathrm{~cm}^{-1}$ ). The bands were observed defining the inorganic composition of the tissue: phosphate groups $\mathrm{PO}_{4}^{3-}\left(567,582,941 \mathrm{~cm}^{-1}\right)$, type $\mathrm{B}$ carbonate ion $\mathrm{CO}_{3}{ }^{-2}$ (1004, 1021, $1054 \mathrm{~cm}^{-1}$ ), and $\mathrm{OH}$ groups of adsorbed lipids and proteins (2952, 3214, $3620 \mathrm{~cm}^{-1}$ ) (see Fig. 1).

\section{Raman spectra of the tissue of autografts harvested from the retromolar region}

When developing markers for detection of the autograft components during the operation, it was found that in the Raman spectrum there were a number of bands corresponding to collagen, blood hemoglobin, proteins (amide II groups of proteins), lipids (C-H groups of fatty acids of lipids), and their $\mathrm{OH}$ groups. In the patient's Raman spectrum of the sample No. 2 a number of bands were observed, which indicated the presence of collagen $\left(1270 \mathrm{~cm}^{-1}\right)$, hemoglobin $(1109,1151$, 1228, 1289, 1353, 1382, 1545, 1570, $\left.1615 \mathrm{~cm}^{-1}\right)$, proteins

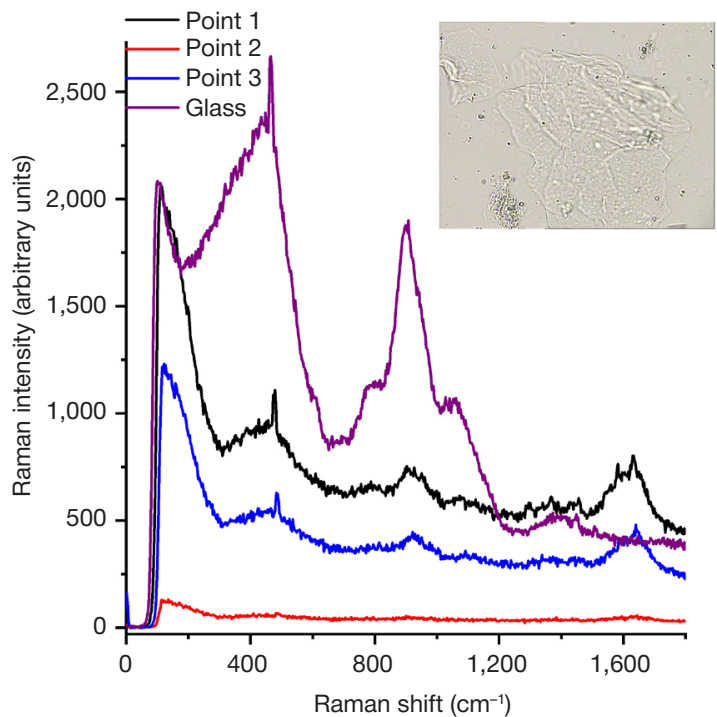

(C-N bonds, 3157, $\left.3204 \mathrm{~cm}^{-1}\right)$, lipids (C-H groups of fatty acids, 2697, 2877, 2911, $2964 \mathrm{~cm}^{-1}$; phosphate groups of phospholipids, 924, $961 \mathrm{CM}^{-1}$ ), and their $\mathrm{OH}$ groups (3402, $3588 \mathrm{~cm}^{-1}$ ) (Fig. 2).

In the patient's Raman spectrum of the sample № 1 a number of characteristic Raman bands were observed, corresponding to vibrations of certain bonds in the protein molecules (for example, $1632 \mathrm{~cm}^{-1}$, amide II of proteins; 2848, 2876, 2918, $2930 \mathrm{~cm}^{-1}$ ), lipids (C-H groups of fatty acids of lipids), and their $\mathrm{OH}$ groups.

\section{Raman spectra of the cells of autografts harvested from the retromolar region}

In order to reveal the markers of distinct cells of the autografts, a number of characteristic bands was detected in the spectrum, corresponding to collagen, red blood cell hemoglobin, proteins (amide and $\mathrm{C}-\mathrm{N}$ bonds), and cellular lipids ( $\mathrm{C}-\mathrm{H}$ groups of fatty acids and phosphate groups of lipids), as well as their $\mathrm{OH}$ groups. In the patient's Raman spectrum of the sample № 1 a number of Raman bands were observed corresponding to proteins and lipids (C-H groups of fatty acids of lipids, 2848,

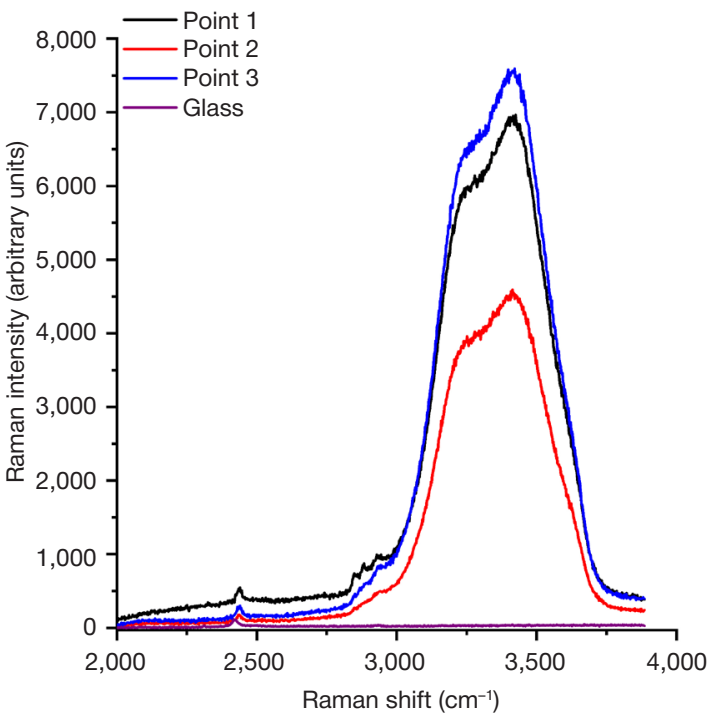

Fig. 3. Raman spectrum of the autograft, sample № 1 (single cell). The insert in the chart illustrates the image of the sample. The control is the Raman spectrum of the glass, the sample is placed on. X-axis: Raman shift $\left(\mathrm{cm}^{-1}\right)$; Y-axis: Raman intensity (in arbitrary units) 

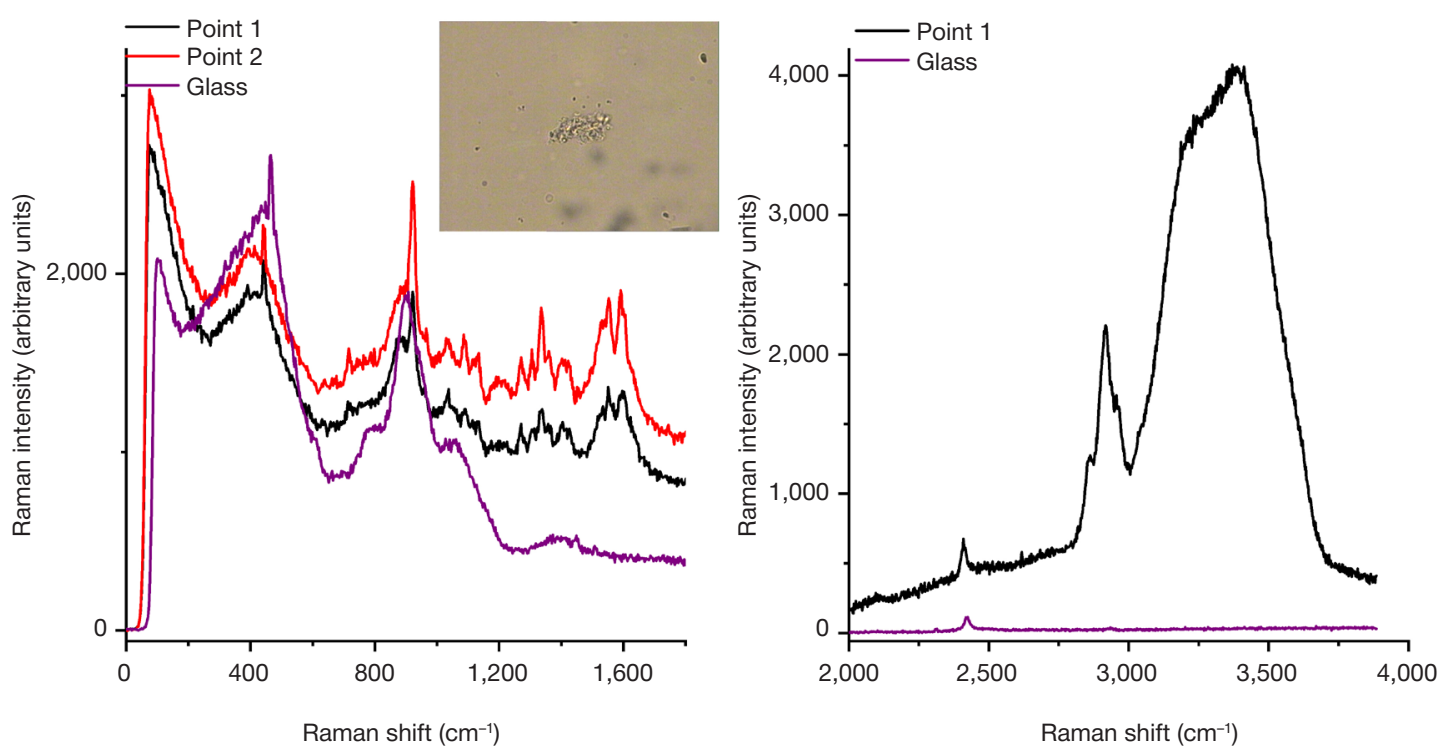

Fig. 4. Raman spectrum of the autograft, sample № 1 (red blood cell). The insert in the chart illustrates the image of the sample. The control is the Raman spectrum of the glass, the sample is placed on. X-axis: Raman shift $\left(\mathrm{cm}^{-1}\right)$; Y-axis: Raman intensity (in arbitrary units)

2876, $\left.2930 \mathrm{~cm}^{-1}\right)$, and their $\mathrm{OH}$ groups (3230, 3420, $3612 \mathrm{~cm}^{-1}$ ) (Fig. 3-5), collagen (1274 $\left.\mathrm{cm}^{-1}\right)$, red blood cell hemoglobin (1303, 1335, 1363, 1407, 1531, 1550, $\left.1593 \mathrm{~cm}^{-1}\right)$, proteins and lipids (phosphate groups, 924, $961 \mathrm{~cm}^{-1}$ ), C-H groups of fatty acids of lipids $\left(2848,2876,2930 \mathrm{~cm}^{-1}\right)$, and their $\mathrm{OH}$ groups (3230, 3420, $3612 \mathrm{~cm}^{-1}$ ) [18-20]. In the patient's Raman spectrum of the sample № 2 there were a number of characteristic Raman bands, corresponding to proteins (amide, 1621; 2841, 2887, $2950 \mathrm{~cm}^{-1}$ ) and lipids (phosphate groups, 888, $\left.1432 \mathrm{~cm}^{-1}\right)$, as well as their $\mathrm{OH}$ groups $(3212$, $\left.3402,3626 \mathrm{~cm}^{-1}\right)$. In the patient's Raman spectrum of the sample No. 2, proteins and lipids were detected ( $\mathrm{C}-\mathrm{H}$ groups of fatty acids of lipids, 2836, 2876, $2946 \mathrm{~cm}^{-1}$ ), as well as their $\mathrm{OH}$ groups $\left(3214,3397,3614 \mathrm{~cm}^{-1}\right)$. In the patient's Raman spectrum of the sample № 3 there were a number of characteristic Raman bands corresponding to collagen (1314 $\mathrm{cm}^{-1}$ and $1603 \mathrm{~cm}^{-1}$ ), proteins (C-N bonds, 2974, 3002, 3932 $\mathrm{cm}^{-1}$ ), lipids (C-H groups of fatty acids of lipids, 2846, 2902, $\left.2938 \mathrm{~cm}^{-1}\right)$, and their $\mathrm{OH}$ groups $\left(3238,3406,3607 \mathrm{~cm}^{-1}\right.$ ) (see Fig. 3-5).

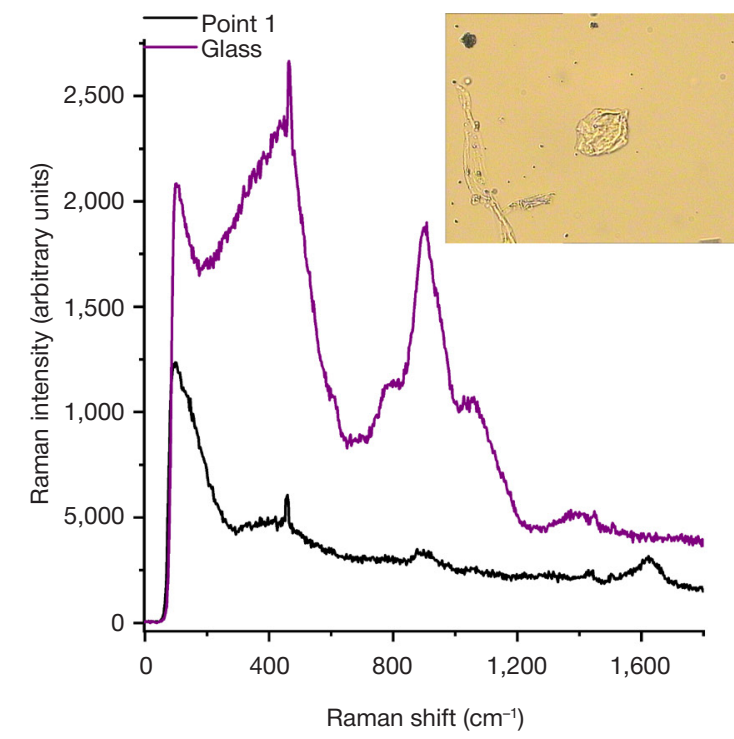

\section{DISCUSSION}

In the course of our study we looked for the possibility of Raman signal acquisition of the molecules of tissues and cells during surgical harvesting of tissue for augmentation of alveolar processes with bone tissue deficiency (elective bone grafting) [15-17]. It's obvious that continuous monitoring of the tissue condition during surgery allows the surgeon to promptly change the surgical procedure and to perform further diagnosis [18-20]. During our study we used the optical non-invasive technique for rapid and effective diagnosis of changes in composition and conformation of molecules in the patient's mandibular cells and tissues. We conducted preliminary research and acquired characteristic signals of bone tissue and periosteum tissue. We assume that the use of fiber optic probes and Raman spectroscopy would make it possible to identify problems and defects occurring during the surgical procedure at the molecular level. It has been found that the bands, indicating the presence of phosphate groups $\left(426,583,938 \mathrm{~cm}^{-1}\right)$ and type $\mathrm{B}$ carbonate ion $\mathrm{CO}_{3}^{-2}\left(1009,1023,1056 \mathrm{~cm}^{-1}\right)$, can be

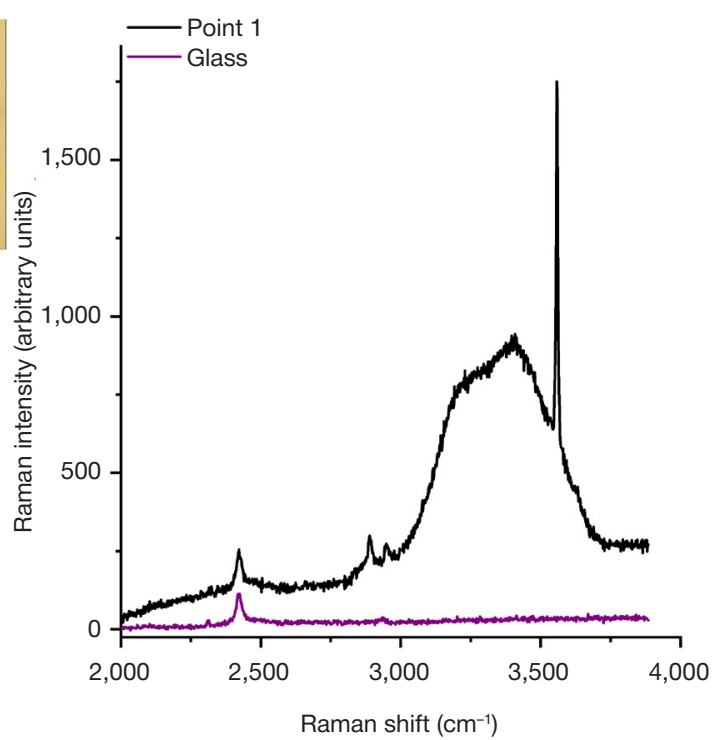

Fig. 5. Raman spectrum of the autograft, sample № 2 (cell). The insert in the chart illustrates the image of the sample. The control is the Raman spectrum of the glass, the sample is placed on. X-axis: Raman shift $\left(\mathrm{cm}^{-1}\right)$; Y-axis: Raman intensity (in arbitrary units) 
considered a characteristic marker for diagnosis of bone tissue condition. This, acquisition of data on these markers makes it possible to evaluate the contribution of these components and the changes of those during the surgical procedure. It is obvious that acquisition of the Raman signal of the cell and tissue population allows to acquire the combined spectrum. In order to identify the specific signal of the periosteum tissue (not bone tissue), the Raman signals have been acquired, indicating the presence of collagen, hemoglobin, various proteins $(\mathrm{C}-\mathrm{N}$ bonds), lipids (C-H groups of fatty acids and phosphate groups of phospholipids), and their $\mathrm{OH}$ groups. Thus, the proposed approach would make it possible to detect changes both in bone tissue and periosteum tissue of the patient's mandible [21, 22].

The important thing about our study is the fact that we have managed to acquire the Raman signals of the distinct cells of autografts, corresponding to distinct molecules of collagen, hemoglobin, proteins and lipids, and their $\mathrm{OH}$ groups.

It has been found that Raman scattering may be used for evaluation of the autograft bone condition during transplantation. The data obtained suggest that the spectra of various autograft samples differ. The proposed method of autograft condition evaluation would be used for identification of certain proteins, lipids, and other molecules, which constitute the bone tissue, as well as for quantification of these molecules. During osseointegration, a large number of biologically active molecules are being synthesized, which may indicate enhanced or decreased integration $[3,6]$.
Thus, Raman signals of specific substances have been acquired in various tissues and cells. Perhaps, the use of advanced equipment and light guides for aquision of signal in the oral cavity during surgery might help to localize the effect on the bone tissue and distinct molecules of the autograft tissue (for example, hemoglobin, collagen, proteins or lipids) or the stem cells of the graft [23].

\section{CONCLUSION}

Thus, in the course of the study it has been found that Raman spectroscopy is appropriate for rapid and efficient assessment of molecular composition, as well as qualitative and quantitative assessment of changes in autograft bone used for mandibular bone augmentation. Early detection of factors, impairing osseointegration, and contributing to resorption of bone tissue surrounding the implant, is a key issue of modern dentistry. Therefore, the research directed to address the issue is essential and relevant. The results obtained allow us to suggest the possibility of using Raman spectroscopy for this purpose. The use of Raman spectra acquisition in combination with detection using light guides would allow the dentist to monitor the process of reparative regeneration and osseointegration during dental implantation. Combination of optical diagnosis and rapid digital feature analysis can significantly improve the efficiency of surgical procedure and treatment.

\section{References}

1. Tsitsiashvili AM, Panin AM. Ustanovka dental'nyh implantatov v distal'nom otdele verhnej cheljusti posle provedenija kostnoj plastiki metodikoj rotacii kostnogo loskuta. Nauchno-prakticheski] zhurnal «Dental Forum». 2017; (2): 40-45.

2. Kulakov AA, redactor. Dental'naja implantacija. Nacional'noe rukovodstvo. M.: GJeOTAR-Media, 2018; 400 s. Available from: https://www.rosmedlib.ru/book/ISBN9785970445419.html.

3. Neugebauer J, Kistler F, Kistler S, Scheer M, Bayer G, Zoller JE. Autologous bone augmentation. Scientific and practical journal "New in Dentistry". 2019; (241): 6-26.

4. Pankratov AS, Lekishvili MV, Kopeckij IS. Kostnaja plastika v stomatologii i cheljustno-licevoj hirurgii. Osteoplasticheskie materialy. M.: Binom, 2011; $271 \mathrm{~s}$

5. Hernandez-Alfaro F, Sancho-Puchades M, Guijarro-Mart'ınez R, Total Reconstruction of the Atrophic Maxilla with Intraoral Bone Grafts and Biomaterials: A Prospective Clinical Study with Cone Beam Computed Tomography Validation. Int J Maxillofac Implants 2013; 28 (1): 241-51. Available from: http://dx.doi.org/10.11607/ jomi.2405.

6. Khoury F, Hanser T. Mandibular bone block harvesting from the retromolar region: a 10-year prospective clinical study. Int J Oral Maxillofac Implants. 2015; 30 (3): 688-97. DOl: 10.11607/jomi.4117.

7. Jureti AM, Cerovi AR, BeluAiA-Gobi AM, Brekalo PrAo I, Kqiku L, Špalj S, et al. Salivary levels of TNF-A and IL-6 in patients with oral premalignant and malignant lesions. Folia Biol (Praha). 2013; 59: 99-102. Available from: https://fb.cuni.cz/file/5685/fb2013a0012.pdf.

8. Feng X, Shi $Y, X u L$, Peng Q, Wang X, Sun W, et al. Modulation of IL-6 induced RANKL expression in arthritic synovium by a transcription factor SOX5. Sci Rep. 2016; 6: 32001. DOI: 10.1038/srep32001.

9. Tereshima A, Takayanagi H. Overview of Osteoimmunology. Calcif Tissue Int. 2018; 102 (5): 503-11. Available from: https://doi. org/10.1007/s00223-018-0417-1.

10. Zorika OA, Abaev ZM, Magomedov RN, Prohodnaya VA, Maksukova ES. Diagnostic value of serum osteomarkets in moderate and severe periodontal disease. Stomatologiya.
2019; 98 (1): 17-20. Available from:https://doi.org/10.17116/ stomat20199801117.

11. Smirnov AV, Rumyantsev ASh. Stroenie i funkcii kostnoj tkani v norme i pri patologii. Soobshhenie I. Nefrologija. 2014; 18 (6): 9-25.

12. Bolevich SB, Vojnov VA. Molekuljarnye mehanizmy $\vee$ patologii cheloveka. Rukovodstvo dlja vrachej. 2012; 206 s.

13. Vlasov AV, Maliar NL, Bazhenov SV, Nikelshparg El, Brazhe NA, Maksimov GV, et al. Raman Scattering: From Structural Biology to Medical Applications. Crystals, MDPI publishing house (Basel, Switzerland). 2020; 10 (1): 38. Available from: https://doi. org/10.3390/cryst10010038

14. Rafalsky VV, Zyubin AYu, Moiseeva EM, Samusev IG. Perspektivy primenenija metoda spektroskopii kombinacionnogo rassejanija sveta (ramanovskoj spektroskopii) $v$ kardiologii. Kardiovaskuljarnaja terapija i profilaktika. 2020; 19 (1): 2394. DOI: 10.15829/1728-8800-2020-1-2394.

15. Eremina OE, Semenova AA, Sergeeva EA, Brazhe NA, Maksimov GV, Shehovcova TN, i dr. Spektroskopija gigantskogo kombinacionnogo rassejanija $v$ sovremennom himicheskom analize: dostizhenija i perspektivy ispol'zovanija. Uspehi himii. 2018; 87 (8): 741-70.

16. Alexandrov MT, Margaryan EG. Rationale for the application of surface-enhanced Raman scattering for identification of main pathogens of purulent-inflammatory diseases in maxillofacial area. 2018; 97 (1); 27-32. DOI: 10.17116/stomat201897127-32.

17. Chen X, Wang Z, Duan N, Zhu G, Schwarz EM, Xie C. Osteoblastosteoclast interactions Connect. Tissue Res. 2017; 59: 99-107. Available from: https://doi.org/10.1080/03008207.2017.1290085

18. Fukumato S, Martin TJ. Bone as an endocrine organ. Trends Endocrinol Metab. 2009; 20 (5): 230-6. Available from: https:// doi.org/10.1038/srep3200.

19. Kylmaoja E, Nakamura M, Tuukkanen J. Osteoclasts and remodeling based bone formation. Curr Stem Cell Res Ther. 2016; 11: 626-33. Available from: https://doi.org/10.2174/15748 88X10666151019115724.

20. Sohrabi K, Mushantat A, Esfandiari S, Feine J. How successful 
are small - diamond implants? The literature review. Clin Oral Implants Res. 2012; 23 (5): 515-25. Available from: https://doi. org/10.1111/j.1600-0501.2011.02410.x.

21. Yunus N, Masood M, Saub R, Al-Hashedi AA, Taiyeb Ali TB, Thomason JM. Impact of mandibular implant prostheses on the oral health-related quality of life in partially and completely edentulous patients. Clin Oral Implants Res. 2016; 27 (7): 904-9.
Available from: https://doi.org/10.1111/clr.12657.

22. Wessel JJ. Surface-enhanced optical microscopy. JOSA B. 1985; 2 (9): 1538-41. Available from: https://doi.org/10.1364/ JOSAB.2.001538.

23. Zhang J, Chen J. Bone Tissue Regeneration - Application of Mesenchymal Stem Cells and Cellular and Molecular Mechanisms. 2017; 12 (5): 357-64. DOI: 10.2174/15748888×11666160921121555.

\section{Литература}

1. Цициашвили А. М., Панин А. М. Установка дентальных имплантатов в дистальном отделе верхней челюсти после проведения костной пластики методикой ротации костного лоскута. Научно-практический журнал «Dental Forum». 2017; (2): 40-45

2. Кулаков А. А., редактор. Дентальная имплантация. Национальное руководство. М.: ГЭОТАР-Медиа, 2018 400 с. Доступно по ссылке: https://www.rosmedlib.ru/book/ ISBN9785970445419.html.

3. Neugebauer J, Kistler F, Kistler S, Scheer M, Bayer G, Zoller JE. Autologous bone augmentation. Scientific and practical journal "New in Dentistry". 2019; (241): 6-26.

4. Панкратов А. С., Лекишвили М. В., Копецкий И. С. Костная пластика в стоматологии и челюстно-лицевой хирургии. Остеопластические материалы. М.: Бином, 2011; 271 с.

5. Hernandez-Alfaro F, Sancho-Puchades M, Guijarro-Mart'ınez R, Total Reconstruction of the Atrophic Maxilla with Intraoral Bone Grafts and Biomaterials: A Prospective Clinical Study with Cone Beam Computed Tomography Validation. Int J Maxillofac Implants 2013; 28 (1): 241-51. Available from: http://dx.doi.org/10.11607/ jomi.2405.

6. Khoury F, Hanser T. Mandibular bone block harvesting from the retromolar region: a 10-year prospective clinical study. Int J Oral Maxillofac Implants. 2015; 30 (3): 688-97. DOI: 10.11607/jomi.4117.

7. Jureti AM, Cerovi AR, BeluAiA-Gobi AM, Brekalo PrAo I, Kqiku L, Špalj S, et al. Salivary levels of TNF-A and IL-6 in patients with oral premalignant and malignant lesions. Folia Biol (Praha). 2013; 59: 99-102. Available from: https://fb.cuni.cz/file/5685/ fb2013a0012.pdf

8. Feng X, Shi $Y, X u L$, Peng Q, Wang X, Sun W, et al. Modulation of IL-6 induced RANKL expression in arthritic synovium by a transcription factor SOX5. Sci Rep. 2016; 6: 32001. DOl: 10.1038/srep32001

9. Tereshima A, Takayanagi $\mathrm{H}$. Overview of Osteoimmunology. Calcif Tissue Int. 2018; 102 (5): 503-11. Available from: https://doi. org/10.1007/s00223-018-0417-1.

10. Зорика О. А., Абаев З. М., Магомедов Р. Н., Проходная В. А., Максюкова Е. С. Диагностическая информативность определения остеомаркеров в сыворотке крови при хроническом парализованном пародонтите средней и тяжелой степени. Стоматология. 2019; 98 (1): 17-20.

11. Смирнов А. В., Румянцев А. Ш. Строение и функции костной ткани в норме и при патологии. Сообщение І. Нефрология. 2014; 18 (6): 9-25

12. Болевич С. Б., Войнов В. А. Молекулярные механизмы в

патологии человека. Руководство для врачей. 2012; 206 с.

13. Vlasov AV, Maliar NL, Bazhenov SV, Nikelshparg El, Brazhe NA, Maksimov GV, et al. Raman Scattering: From Structural Biology to Medical Applications. Crystals, MDPI publishing house (Basel, Switzerland). 2020; 10 (1): 38. Available from: https://doi. org/10.3390/cryst10010038.

14. Рафальский В. В., Зюбин А. Ю., Моисеева Е. М., Самусев И. Г. Перспективы применения метода спектроскопии комбинационного рассеяния света (рамановской спектроскопии) в кардиологии. Кардиоваскулярная терапия и профилактика. 2020; 19 (1): 2394.

15. Еремина О. Е., Семенова А. А., Сергеева Е. А., Браже Н. А., Максимов Г. В., Шеховцова Т. Н., и др. Спектроскопия гигантского комбинационного рассеяния в современном химическом анализе: достижения и перспективы использования. Успехи химии. 2018; 87 (8): 741-70.

16. Alexandrov M. T., Margaryan E. G. Rationale for the application of surface-enhanced Raman scattering for identification of main pathogens of purulent-inflammatory diseases in maxillofacial area. 2018; 97 (1); 27-32. DOI: 10.17116/stomat201897127-32.

17. Chen X, Wang Z, Duan N, Zhu G, Schwarz EM, Xie C. Osteoblastosteoclast interactions Connect. Tissue Res. 2017; 59: 99-107. Available from: https://doi.org/10.1080/03008207.2017.1290085.

18. Fukumato $S$, Martin TJ. Bone as an endocrine organ. Trends Endocrinol Metab. 2009; 20 (5): 230-6. Available from: https:// doi.org/10.1038/srep3200

19. Kylmaoja E, Nakamura M, Tuukkanen J. Osteoclasts and remodeling based bone formation. Curr Stem Cell Res Ther. 2016; 11: 626-33. Available from: https://doi.org/10.2174/15748 88X10666151019115724.

20. Sohrabi K, Mushantat A, Esfandiari S, Feine J. How successful are small - diamond implants? The literature review. Clin Oral Implants Res. 2012; 23 (5): 515-25. Available from: https://doi. org/10.1111/j.1600-0501.2011.02410.x.

21. Yunus N, Masood M, Saub R, Al-Hashedi AA, Taiyeb Ali TB, Thomason JM. Impact of mandibular implant prostheses on the oral health-related quality of life in partially and completely edentulous patients. Clin Oral Implants Res. 2016; 27 (7): 904-9. Available from: https://doi.org/10.1111/clr.12657.

22. Wessel JJ. Surface-enhanced optical microscopy. JOSA B. 1985; 2 (9): 1538-41. Available from: https://doi.org/10.1364/ JOSAB.2.001538.

23. Zhang J, Chen J. Bone Tissue Regeneration - Application of Mesenchymal Stem Cells and Cellular and Molecular Mechanisms. 2017; 12 (5): 357-64. DOI: 10.2174/1574888x11666160921121555. 